Primljen / Received: 11.7.2012

Ispravljen / Corrected: 17.10.2012.

Prihvaćen / Accepted: 23.10.2012.

Dostupno online / Available online: 15.11.2012.

\section{Selection of steel based on ductility}

\section{Authors:}

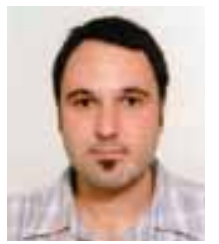

Asst.Prof. Davor Skejić, PhD. CE

University of Zagreb

Faculty of Civil Engineering

davors@grad.hr

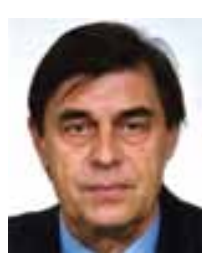

Prof. Boris Androić, PhD. CE

I.A. projektiranje d.o.o., Zagreb

info@iaprojektiranje.com

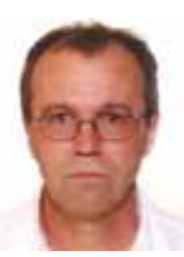

Prof. Darko Dujmović, PhD. CE

University of Zagreb

Faculty of Civil Engineering

dujmovic@grad.hr

\section{Davor Skejič, Boris Androić, Darko Dujmović}

\section{Selection of steel based on ductility}

Designers are nowadays at difficulty when selecting proper steel grade, as over 2500 types of steel are available on the market. Specific requirements for the avoidance of brittle fracture are defined in EN 1993-1-10. The method for safety assessment with regard to avoidance of brittle fracture via fracture mechanics, and theoretical background of structural rules defined in EN 1993-1-10, are presented in the paper. In addition to the normal use of EN 1993-1-10, its other uses, in case of specific ductility requirements due to high strain rate and/or high cold strain effects, are also presented.

\section{Key words:}

steel selection, Eurocode, EN 1993-1-10, ductility, brittle fracture, fracture mechanics

Pregledni rad

\section{Davor Skejić, Boris Androić, Darko Dujmović}

\section{Izbor čelika s obzirom na žilavost}

Činjenica da danas postoji više od 2500 vrsta čelika uvelike otežava ispravan izbor pri projektiranju. Specifični zahtjevi za izbjegavanje krtog loma definirani su u EN 1993-110. U radu je prikazana metoda procjene sigurnosti za izbjegavanje krtog loma preko mehanike loma, kao i teorijska pozadina inženjerskih pravila definiranih u EN 1993-1-10. Osim uobičajene primjene EN 1993-1-10, pokazane su mogućnosti njene primjene kod specifičnih zahtjeva žilavosti zbog visoke stope prirasta deformacije i/ili visokih učinaka hladne deformacije.

Ključne riječi:

izbor čelika, Eurokod, EN 1993-1-10, žilavost, krti lom, mehanika loma

Übersichtsarbeit

Davor Skejić, Boris Androić, Darko Dujmović

\section{Die Auswahl von Stahl unter dem Aspekt der Festigkeit}

Die Tatsache, dass es heute mehr als 2500 Stahlsorten gibt, erschwert bei der Planung die richtige Auswahl erheblich. Die spezifischen Anforderungen zur Vermeidung eines Sprödbruchs sind in EN 1993-1-10 definiert. In der Arbeit wird eine Methode zur Beurteilung der Sicherheit für die Vermeidung eines Sprödbruchs über die Bruchmechanik sowie auch der theoretische Hintergrund der Ingenieursregeln dargestellt, die in EN 1993-1-10 definiert sind. Neben der gewöhnlichen Anwendung von EN 1993-1-10 werden auch Möglichkeiten ihrer Anwendung bei spezifischen Festigkeitsanforderungen aufgrund einer hochgradigen Deformationszunahme und/oder hoher Einwirkung von Kaltverformung gezeigt.

Stahlauswahl, Eurocode, EN 1993-1-10, Festigkeit, Sprödbruch, Bruchmechanik 


\section{Introduction}

\subsection{General considerations about steel choice according to Eurocode}

Eurocode 3 [1] deals with the design of steel structures, and with construction works involving steel. It is compliant with requirements and principles for the reliability of structures, and with basic principles of their design and verification as set out in EN 1990 - Basis of Structural Design [2]. The requirements have been set for the resistance, usability and fire resistance of steel structures. They are based on the principle of design according to limit states, in which it is usually assumed that the resistance of the cross-section and element to ultimate limit states is based on tests in which tolerances according to EN 1090-2 are met, and the material shows ductility that is sufficient for the application of simplified computation models. Therefore, material properties (for steel: grade (class) of steel) must be specified in detail, in accordance with reliability levels defined in Eurocode 3.

These simplified computation models and reliability concept from Eurocode are based on tests conducted at ambient temperature, when ductile failure occurs because the toughness of steel is sufficient in the upper range. All ductile forms of failure that are included in design rules for steel structures, and expressions for typical resistance and partial factor values resulting from the testing, are presented in Figure 1 (left side). In case of brittle fracture, the assumptions for computation models and safety concepts are no longer met, cf. Figure 1 (right side). Consequently, the brittle fracture must be avoided by selecting adequate steel that is characterized by sufficient toughness.

\subsection{Choice of an appropriate steel grade}

In general, the selection of proper steel grade is defined in EN 1993-1-1 [1]. Some of the requirements are given below:

1. mechanical properties - nominal values of material properties are defined as typical values in the analysis;

2. ductility requirements - minimum ductility is required for steel;

3. toughness properties - simplified rules are given for selection of an appropriate material, i.e. of the material whose toughness is sufficient to prevent brittle fracture;

4. through thickness properties - guidelines for selection of through thickness properties are given in EN 1993-1-10, [4].

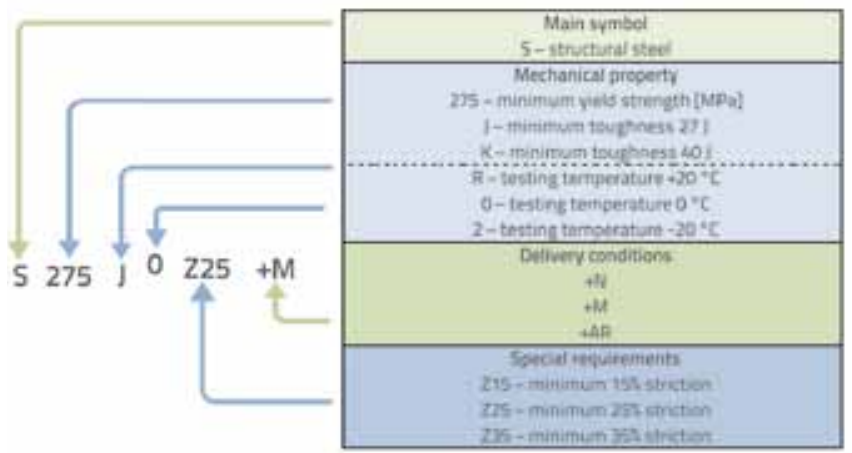

Figure 2. Designation of steel grade in accordance with EN 10025 [5]

With regard to these requirements, steel grades are specified in the standard for hot rolled products of structural steels EN 10025 [5], cf. Figure 2. The alphanumeric steel designation method, presented in this text and adopted in EN 10025, is

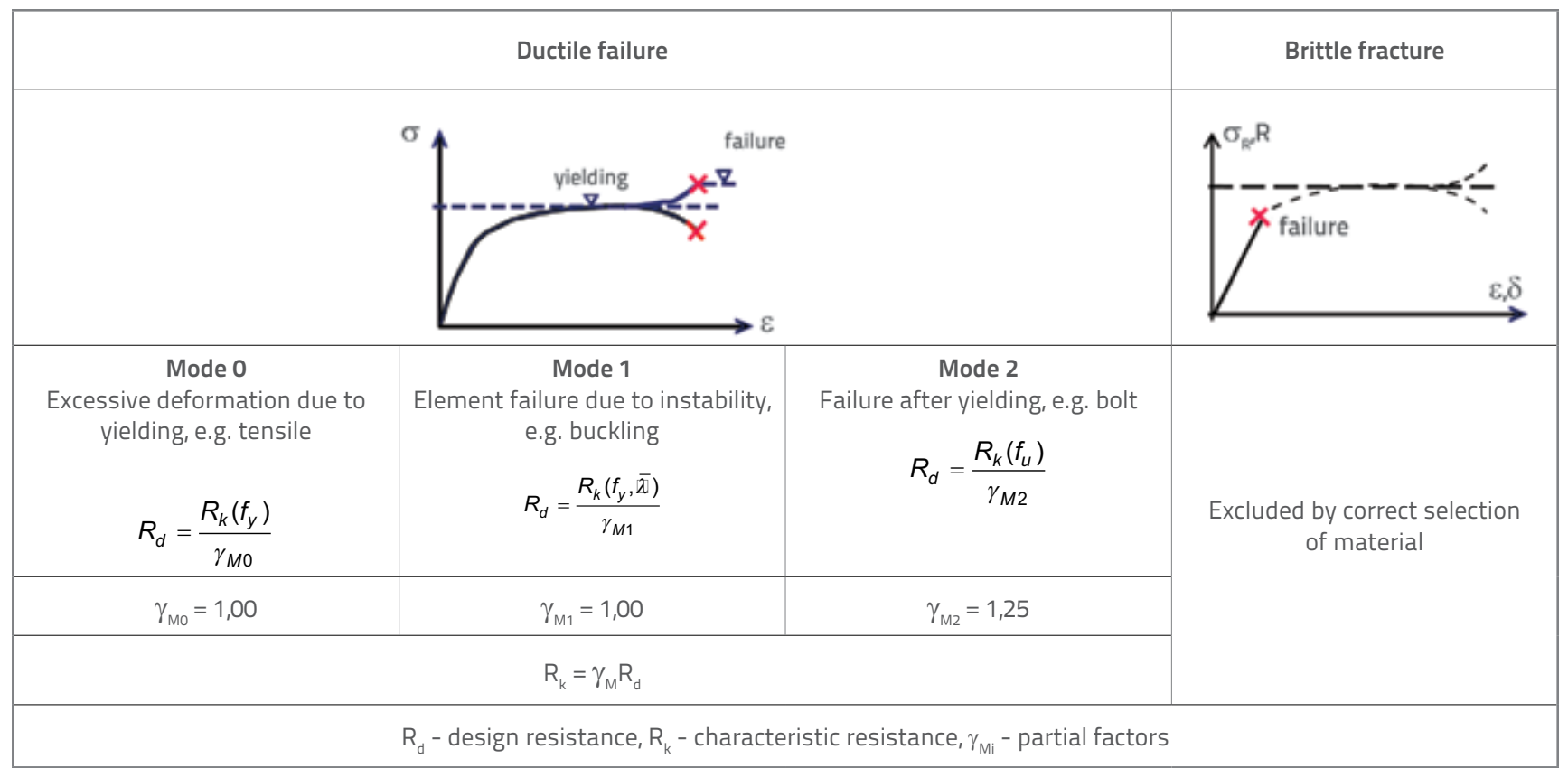

Figure 1. Brittle fracture and modes of ductile failure [3] 
defined in accordance with standards EN 10027-1 and CR 10260. The classification of steel grades is therefore based on the above-mentioned minimum yield limit at ambient temperature.

\section{Requirements for the choice of steel}

\subsection{Mechanical properties}

Nominal values of yield limit, fy, and strength, $f_{u^{\prime}}$ for structural steel should be obtained by adopting the values $f_{u}=R_{e h}$ and $f_{u}$ $=R_{m}$ directly from standards for produyts [5], or from the table 3.1 contained in EN 1993-1-1 [1], which is in fact taken over from [5]. It is important to note that the required yield limit reduces with an increase in material thickness. This takes into consideration the fact that more alloying elements should be added with an increase in material thickness in order to achieve the constant yield limit across thickness. However, the carbon equivalent value increases with an increase in addition of alloying elements, and welding becomes problematic. Weldability is an important property for the use of structural steels. That is why this fact has been taken into account in standardized rules by reducing the required yield limit for thicker plates so as to enable proper weldability. At this point, it should be noted that new methods for the production of thermomechanical rolled fine-grained steels in quality grades equal to or greater than $\mathbf{S 4 6 0}$ have enabled achievement of excellent mechanical properties, i.e. a small reduction of yield limit with an increase in thickness. These steels, known in practice under the commercial name of HISTAR, are characterized by exceptional weldability which, in addition to the abovementioned advanced mechanical properties, is the result on the new way of manufacture of high-quality steels with a small content of alloying elements and, generally, with a small equivalent carbon content.

\subsection{Ductility}

Ductility is inter alia specified so as to avoid brittle fracture of structural elements. The minimum ductility of steel is expressed in form of limitations for:

- elongation after fracture at the measurement length of $5,65 \sqrt{ } A_{0}$ (gdje je $A_{0}$ is the initial surface of cross section). According to Eurocode, the elongation after fracture should not be less than $15 \%$;

- $f_{u} / f_{y}$ ratio of a specified minimum strength, $f_{u^{\prime}}$ and a specified minimum yield strength $f_{y^{\prime}}$ According to Eurocode, the minimum value should be $f_{u} / f_{y} \geq 1.10$.

Both criteria are of particular significance for high-strength structural steels, such as for instance the grade HISTAR 460 (or steel grade $\mathbf{5 4 6 0}$ according to EN 10025-4 for thermomechanical rolled weldable fine-grained structural steels), taking into account the fact that the greater the yield limit the smaller the elongation after fracture, Figure 3 . The minimum elongation of structural steels is specified in [5]. Consequently, the products standard offers more ductility than that required in EN 1993-1-1. However, it can be seen in Figure 3 that the minimum elongation requirement is generally met with a high level of reliability for modern generation of high-strength steels.

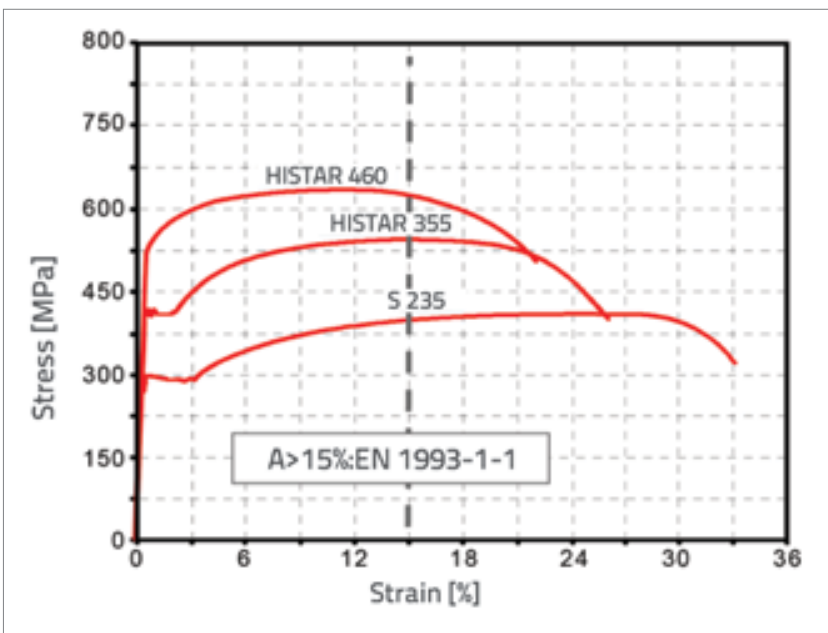

Figure 3. Comparison of stress-strain curves for steel S235 and modern generation steels

The $f_{u} / f_{y}$ ratio is generally more critical when compared to minimum elongation. That is why numerous tensile tests have been conducted, and the $f_{u} / f_{y}$ ratios obtained are presented with respect to yield limit in Figure 4 [6].

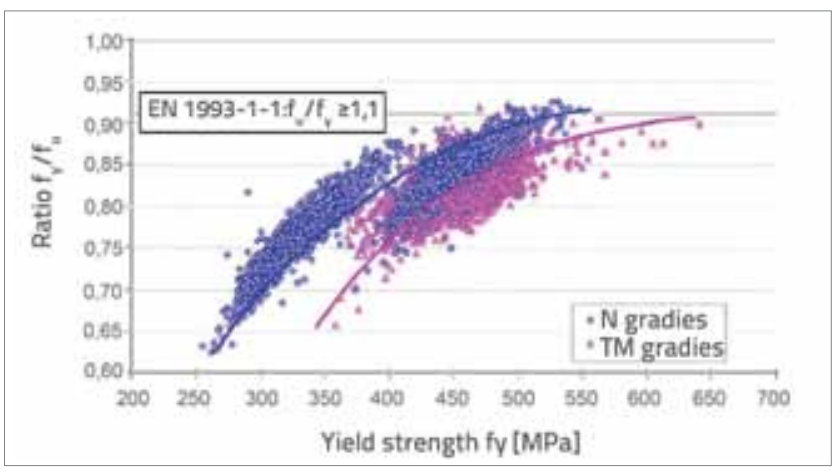

Figure 4. Yield limit and strength ratio of structural steel produced by Arcelor/Mittal [6], N - normalized steels, TM thermomechanically steels

It can be concluded from the diagram shown in Figure 4 that structural steels of up to $460 \mathrm{MPa}$ fulfil ductility requirements. At the first glance, it seems that structural steels with yield limit in excess of $460 \mathrm{MPa}$ do not fulfil ductility requirements. However, steels produced by the thermomechanical (TM) procedure actually do fulfil these requirements thanks to their specific hardening mechanism (refined microstructure and reduced microalloyant content). 


\subsection{Toughness}

There are two ways in which failure can occur: ductile or brittle (Table 1). Brittle failure is an undesirable sudden failure without plastic deformation of material, and is usually called brittle fracture. Toughness is the resistance of material under load to brittle fracture. Toughness is defined as the quantity of energy per unit volume that the material can absorb prior to failure. The toughness of material is influenced by several factors:

\section{- Temperature}

Materials lose their resistance to failure with the reduction of temperature, cf. Figure 5. This relationship can be shown in the curve: impact energy (KV) - Temperature ( $T$ ) with the upper range (3: ductile failure), lower range (1: brittle fracture) and transitional range (2: mixed fracture fracture presents traces of splitting and shearing surface).

- Loading speed

The higher the loading speed the lower the toughness, cf. Figure 6.

\section{- Grain size}

The crystal lattice orientation is different in neighbouring grains, cf. Figure 7. Whenever the tip of the crack reaches the grain limit, the crack subsequently changes its direction of spreading (growth) and so the energy is disintegrated. Consequently, finer-grained steels are more resistant to brittle fracture.

- cold forming

The yield limit increases with an increase in cold forming and with the reduction in ductility, cf. Figure 8.

- Thickness of material

In two-dimensional state of stress, the plastic deformation of steel starts in the point of elongation. In three-dimensional state of stress, the crystal lattice of steel is contained (compressed) from all sides, which results in significant increase of the yield limit of steel. Consequently, thinner plates with greater proportion of material in two-dimensional state of stress have greater ductility when compared to thicker plates, cf. Figure 9.

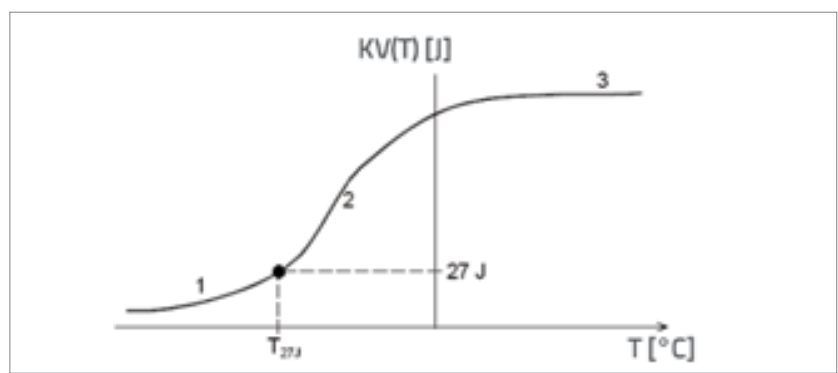

Figure 5. Impact energy KV - temperature T curve

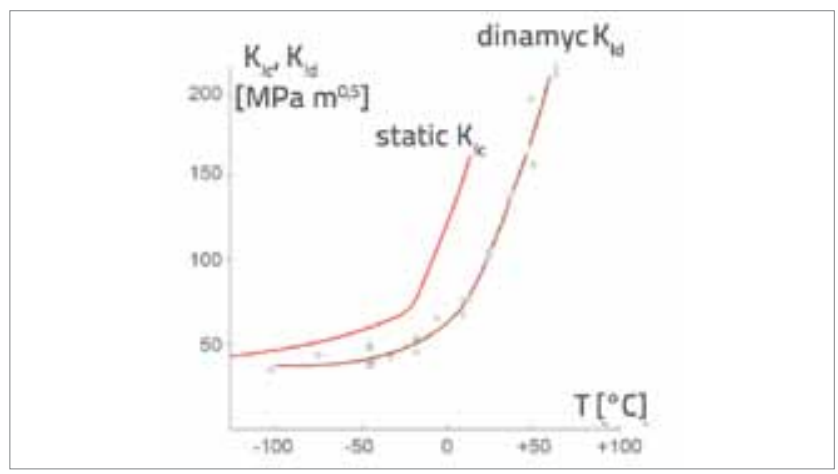

Figure 6. Stress intensity - temperature curve for quasi-static and dynamic load

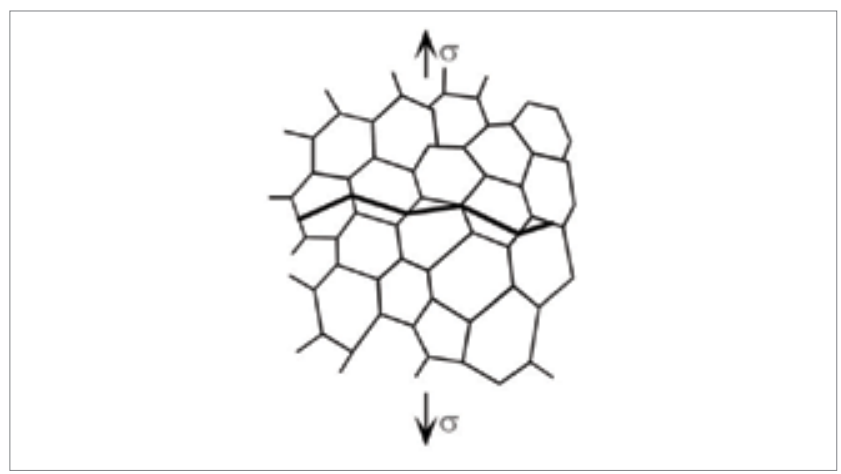

Figure 7. Model of crack propagation across microstructure

Table 1. Material failure mechanisms [7]

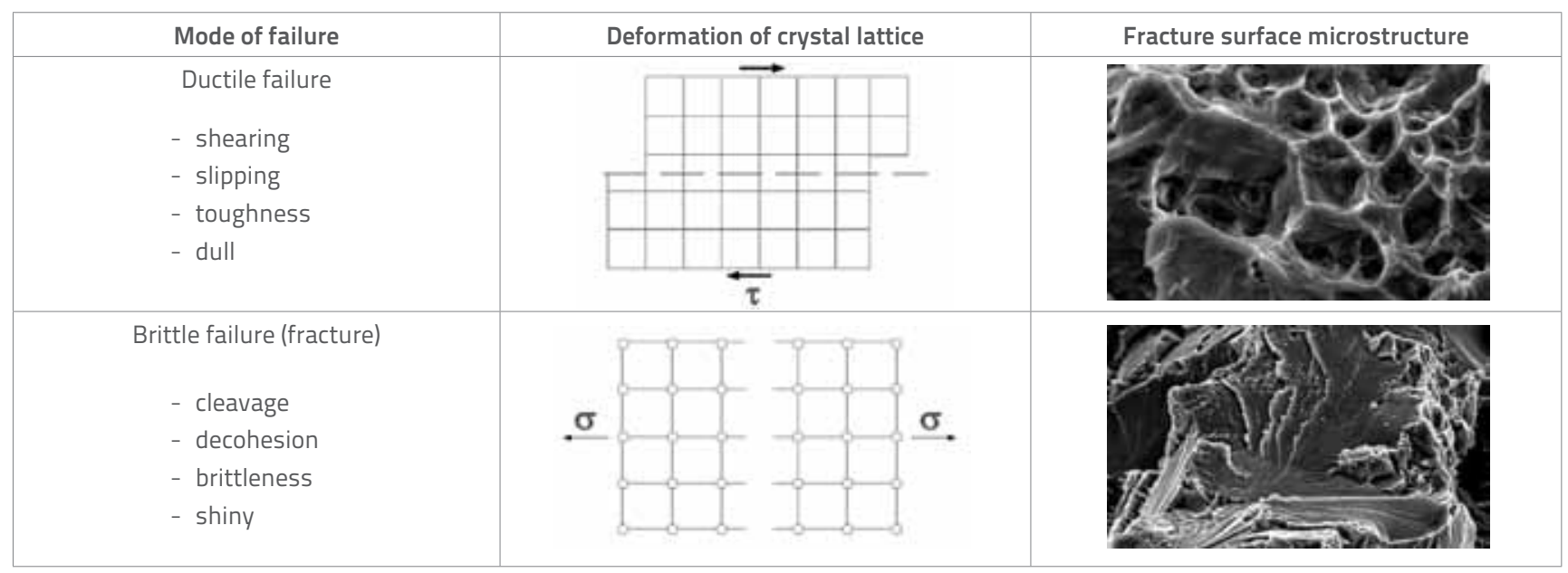




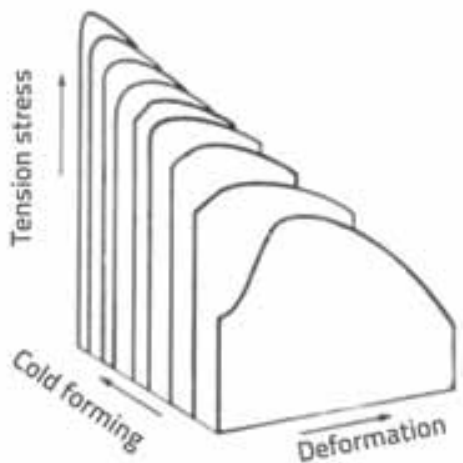

Figure 8. Stress-strain curve as related to cold forming degree

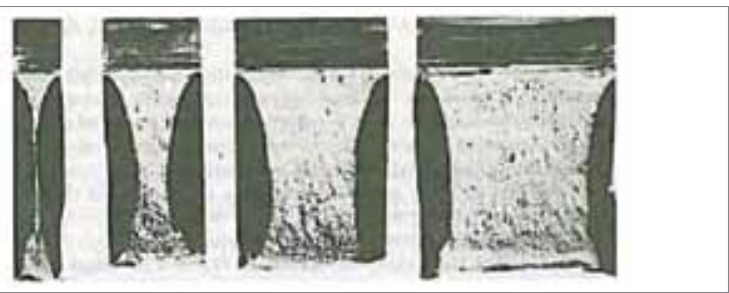

Figure 9. Fracture surface after Charpy's impact tests on plates of different thickness

Toughness is normally determined by means of Charpy impact test during which the impact energy - temperature curve is obtained.

Other relevant factors that are also significant for the element's resistance to brittle fracture are:

- Detail (form) of notch

The initial appearance of the crack is greatly dependant on the notch detail, resulting stress, crack position, and crack form expressed through stress intensity factor.

- Element deterioration level (relationship between action effects and resistance)

The greater the tensile stress in the element, the greater the fracturing probability.

\subsection{Through thickness properties}

Lamellar tearing is a type of fracture that is initiated below the weld, cf. Figure 10. It usually occurs when plate-shaped materials of low ductility are welded in the direction of thickness (or through thickness) onto a perpendicular element. Failure due to tearing usually occurs within the base metal outside of the zone of influence of heat, and is parallel to the weld melting limit. The problem is caused by welds that expose the base material to high stresses, i.e. to shrinkage in the through-thickness direction. The main indicator that the material exhibits deformability in the through-thickness direction is sulphur (contained in steel as a residual element). However, it is known that the deformability itself, but not the strength (resistance) in the through-thickness direction, can be improved through appropriate steel manufacturing procedures.

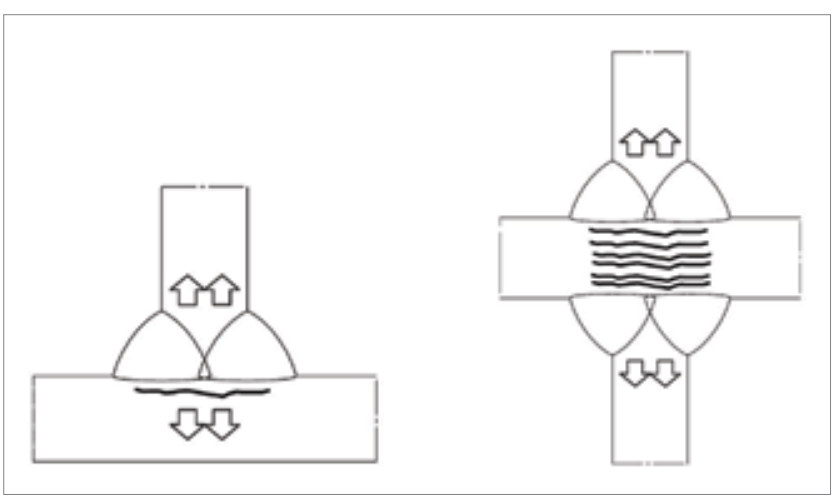

Figure 10. Lamellar tearing [3]

The resistance to lamellar tearing is one of significant requirements to be considered during steel selection. However, in this paper the emphasis is placed on toughness requirements, and so this issue will no further be considered, primarily because of space limitations.

\section{Fracture mechanics safety assessment to avoid brittle fracture}

The fracture mechanical safety assessment to avoid brittle fracture, as specified in Eurocode 3, Part 1-10 - Material toughness and through thickness properties [4] is presented below. More information can be found in [7].

The assessment is made by comparing the $\mathrm{K}$-values (stress intensity factors), cf. expression (1). Design values of the action effects, expressed through the stress intensity factor, $K^{*}{ }_{\text {appl,d }}$ are compared with the design values of the resistance, expressed through the stress intensity factor, $K^{*}{ }_{\text {mat, }, d^{*}}$

$K_{a p p l, d}^{*} \leq K_{m a t, d}$

1. structural component has a flaw in form of a hole at the maximum stress concentration point (hot spot), $a_{d}$ (e.g. design value of the crack depth), which is also exposed to residual stress from fabrication;

2. temperature of the structural component, $\left(T_{\text {min, } d}\right)$, achieves its minimum value and causes minimum toughness properties;

3. structural component is exposed to stress due to permanent and variable load, with the leading action ( $\left.T_{\text {min, }}\right)$

4. the design situation encompassing a combination of the above assumptions is accidental.

Using the K-value for assessment, cf. expression (1), the advantage of the Sanz correlation can be used between the fracture mechanics value KV and the value obtained from the Charpy impact test with V-notch, as indicated in steel supply standards, and this in such a way that steel can be selected without reference to toughness data defined for a specific project. 


\subsection{Toughness requirements}

The toughness requirements, $K^{*}$ appl,d resulting from stress values entered, can be determined for some given details, as shown in Figure 11 on the example of the welded connection at the bottom flange of the beam.

Stresses $\sigma_{E d}$ are a part of the yield limit which results from:

a) frequent load combination

where $G_{k}$ is typical value of permanent load, $Q_{k}$ is typical value of variable load, and $\psi_{2}$ is the factor for the quasiconstant variable action [2];

b) residual stresses $\sigma_{s}$ in the tensile flange of the beam due to shrinkage effects during beam manufacture. Local residual stresses in the critical hot spot, e.g. due to connection welding, are included in the verification procedure.

$G_{k}+\psi_{2} Q_{k}$
The $K^{*}$ appl,d value is defined in two steps:

1. determination of linear elastic value $K_{\text {appld }}$ (for instance by means of $\Delta K\left(a_{d}\right)$

2. modification of $K_{a p p l, d}$ so as to obtain $K^{*}$ appl,d through CEGB R6 failure assessment diagram, which takes into account local plasticization of crack tips.

\subsection{Toughness resistance}

The toughness resistance $K_{\text {mat, }}\left(T_{E d}\right)$ is calculated from a specified impact energy $K V$ expressed through temperatures $T_{K V}$ for which minimum impact energy $K V$ is achieved (e.g. $T_{271}$ for $K V=27 \mathrm{~J})$, and from minimum temperature of structural part $T_{E d^{\prime}}$ as input values, cf. Figure 12.

The value $K_{\text {mat }}\left(T_{E d}\right)$ can be obtained using the Sanz correlation for connecting $T_{27 \mathrm{~J}}$ with the stress intensity factor, $T_{27 \mathrm{~J}}$, and the Wallin curve for determining the $K_{\text {mat }}$ from $K_{100}$ and $T_{\text {min,d }}$. The procedure is reduced to introduction of an additional safety

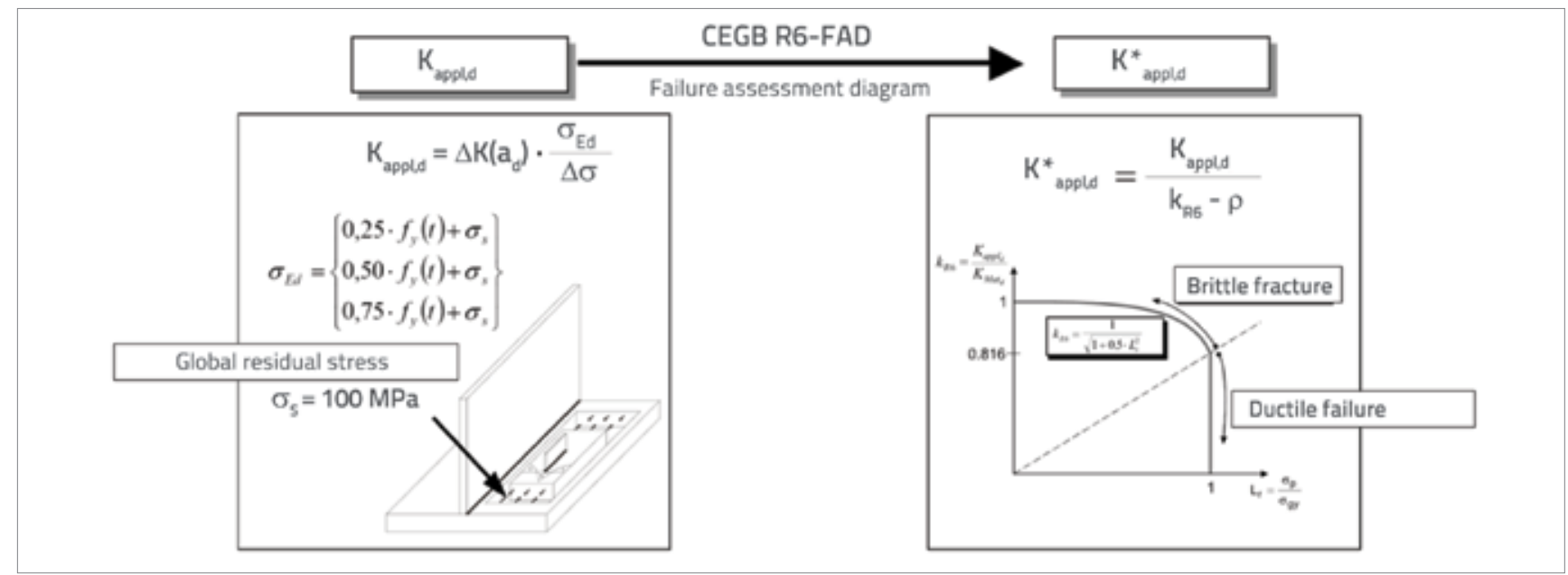

Figure 11. Determining the toughness requirement $\mathrm{K}^{*}{ }_{\text {appl,d }}[7]$

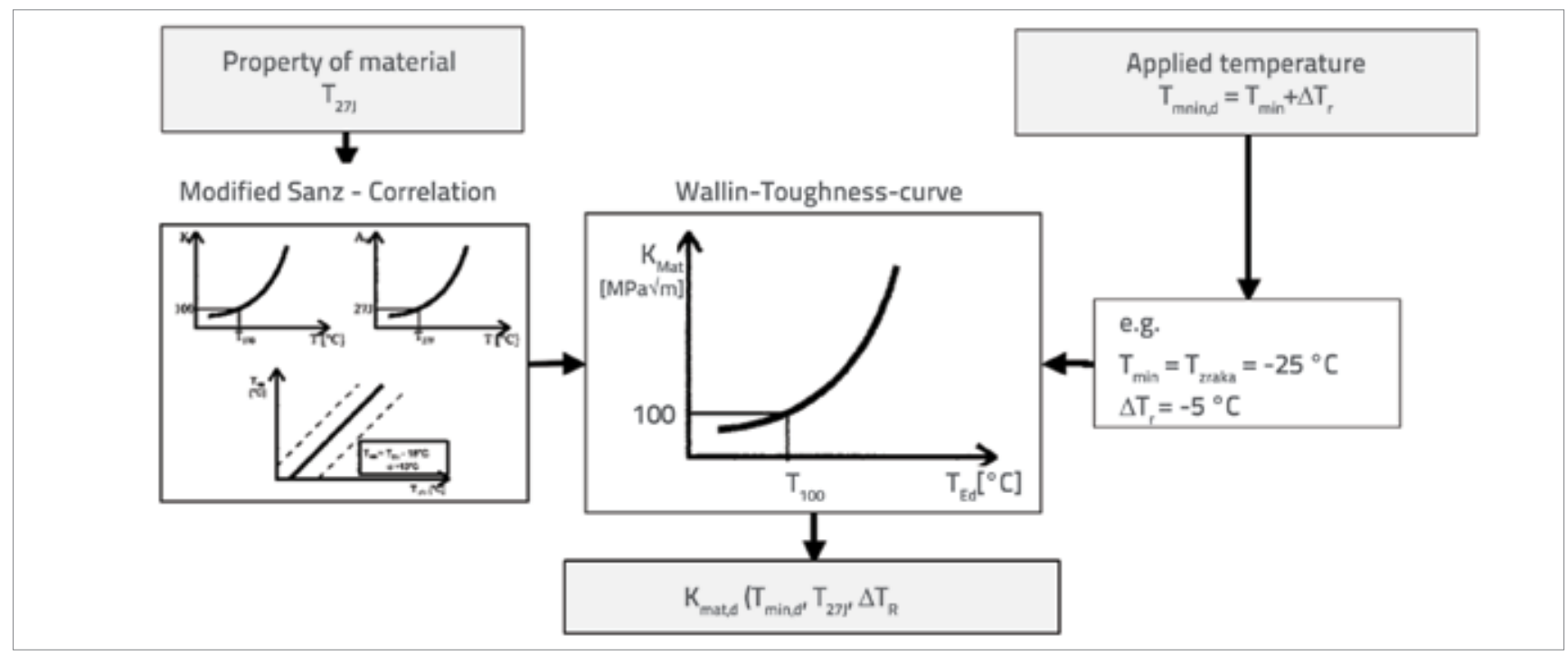

Figure 12. Determination of the toughness resistance $K_{\text {mat }}\left(T_{E d}\right)[7]$ 
element $\Delta T_{R}$ by which $T_{\min , d}$ is moved so that the reliability that is sufficient for proving purposes can be obtained.

\subsection{Safety assessment method}

As already indicated, cf. expression (1), the safety assessment transforms into temperature values and hence assumes the form presented in expression (3) (cf. Figure 13):

$T_{E d} \geq T_{R d}$

where $T_{R d}$ is the temperature at which the safety level of fracture toughness can be associated with estimated conditions specified in the scope of the definition of the toughness resistance (Section 3.3), while $T_{E d}$ is the reference temperature which includes all input values by taking them into account at the change (variation) of temperature. Input values are:

- lowest air temperature, $T_{\text {min' }}$ (temperature map for the standard 50-year return period),

- losses due to component radiation $(\Delta T)$

- influence of the element shape and size, crack imperfection, and stress $\sigma_{E d^{\prime}}$ which results in $\left(\Delta T_{s}\right)$

- additional safety element $\left(\Delta T_{R}\right)$
- influence of deformation increase rate $\left(\Delta T_{\dot{\varepsilon}}\right)$

- influence of cold shaping $\left(\Delta T_{\varepsilon_{c}}\right)$.

Calculation details are shown in Figure 13. The resistance side contains only the test value $T_{27}$ and temperature movement of $18^{\circ} \mathrm{C}$ which is caused by the Sanz correlation.

An additional safety element $\Delta T_{R}$ is obtained from calibration for the data base relating to testing of big samples, which contains tests conducted on various steel qualities, and various welded connections, including local residual stresses and cracks $a_{d}$ caused by artificial initial cracks that propagate due to variable load.

\subsection{Standardisation of material choice}

Tables with allowable structural element plate thicknesses, with most frequent structural details depending on the quality of steel, toughness properties, reference temperatures $T_{E d}$ and stress levels $\sigma_{E d^{\prime}}$ are needed so as to enable simplification of the material selection procedure. For that purpose, assumptions have been made, for various structural details, for initial surface cracks with depths $a_{0}$ (cf, Figure 14) that are exposed to propagation toward the depth $a_{0}$ using the

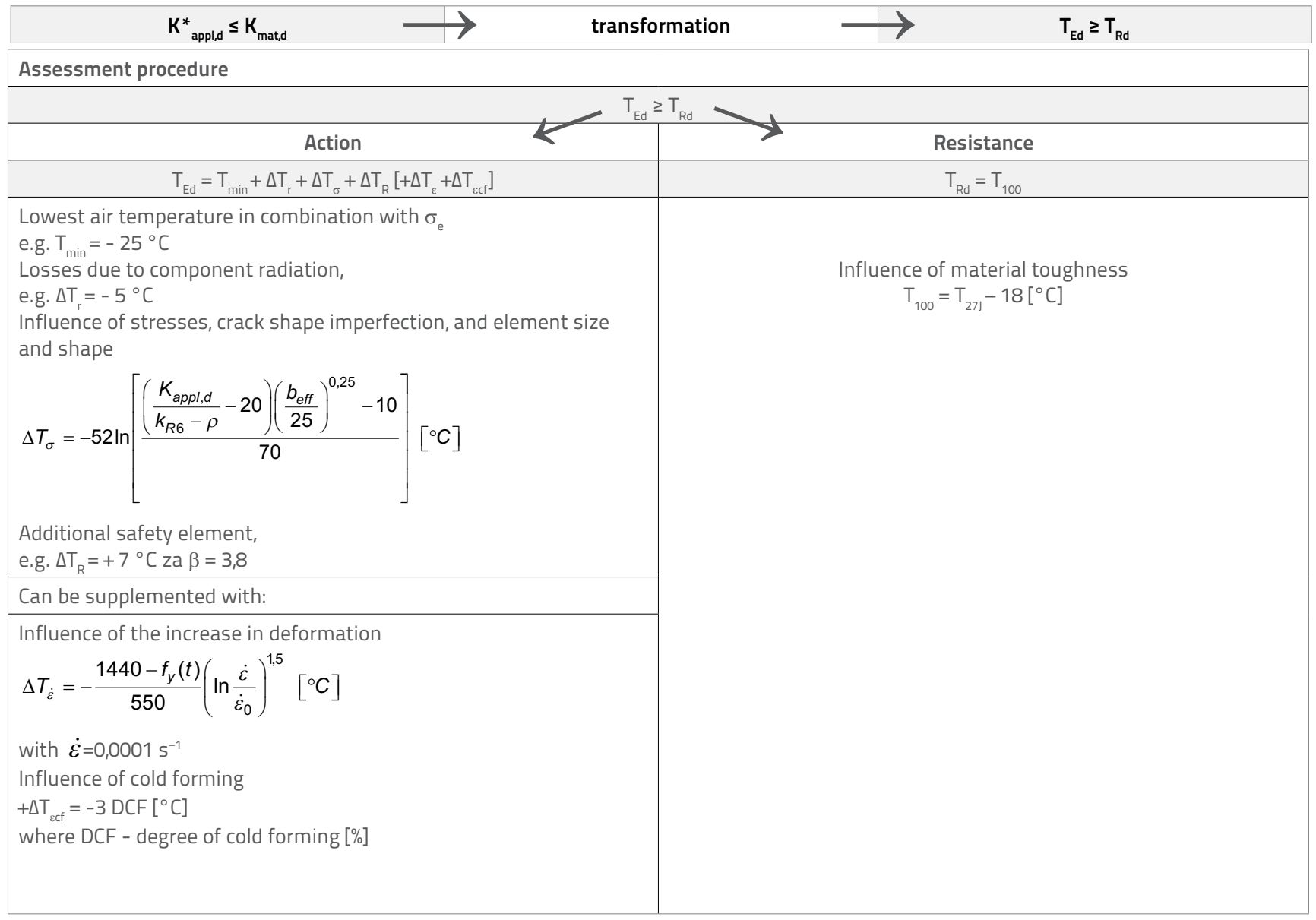

Figure 13. Safety assessment procedure based on temperature $T_{E d} \geq T_{R d}[7]$ 
reference variable load that causes fracture due to fatigue and depends on the detail category $\Delta \sigma_{c}$ according to [8] and corresponds to one-fourth of the total damage due to fatigue $D=1$.

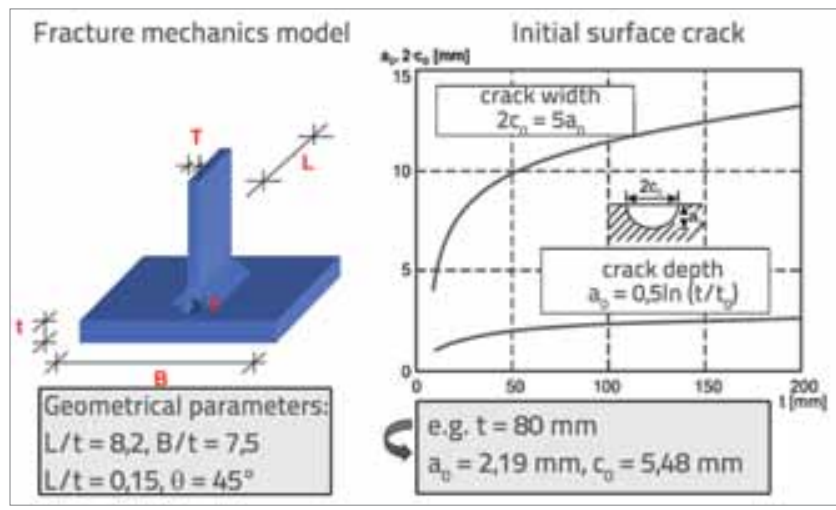

Figure 14. Assumptions for details and initial sizes of surface cracks

Toughness requirements expressed as $\Delta T \sigma$, obtained in this way for various detail categories specified in EN 1993-1-9 [8], and enveloping standard requirement curves obtained from these calculations, are presented in Figure 15.

An appropriate table for the selection of materials (Table 2.1), based on this standard requirement curve, is given in EN
1993-1-10, [4]. In addition to standard grades of steel, this table also contains high-strength grades S460 and S690.

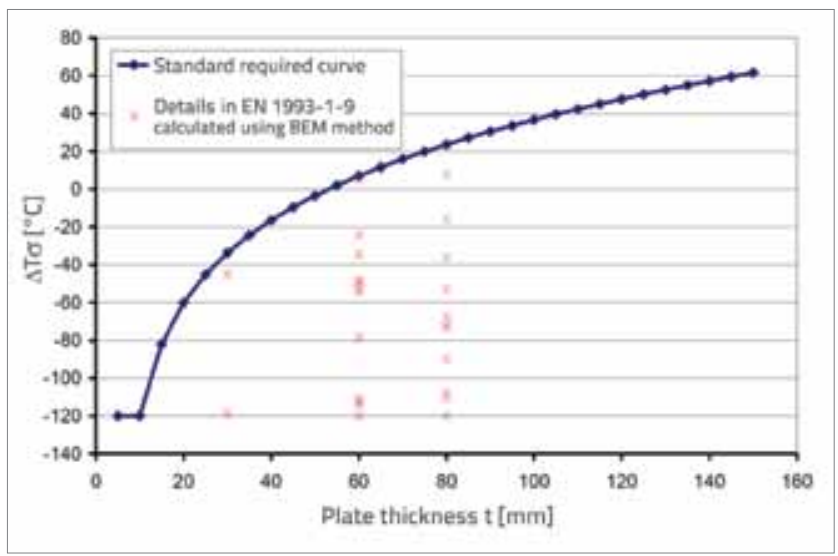

Figure 15. Enveloping standard toughness requirement curve for details according to EN 1993-1-10

\section{Choice of steel for practical applications}

\subsection{Standard practice in bridge construction}

Steel for the bottom flange of the beam must be selected for a composite road bridge with the cross section as shown in

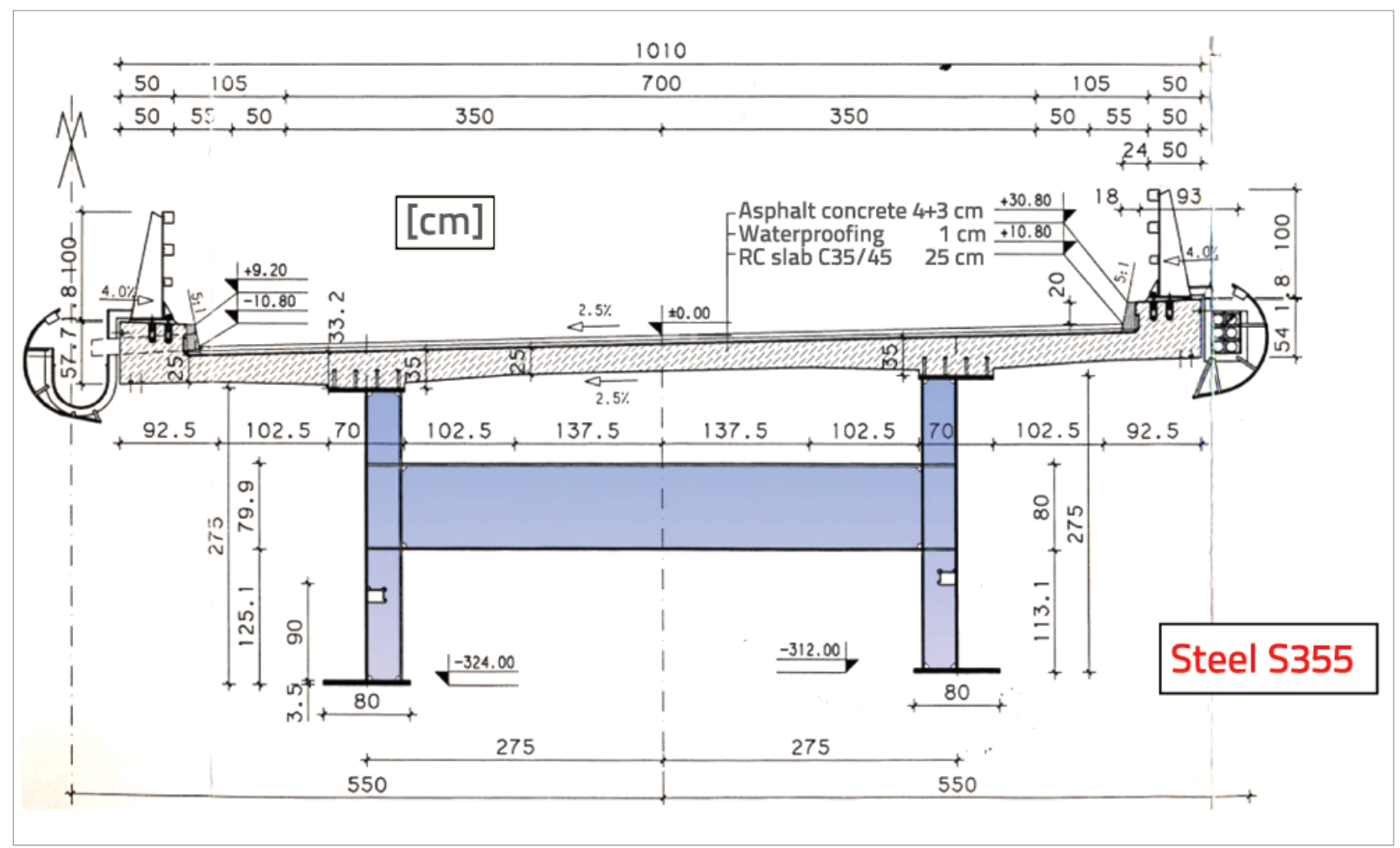

Figure 16. Cross section in mid span of a composite bridge (continuous girder), and cross-sectional dimensions of a steel girder in mid span (Mirna Viaduct, Istria, Croatia) [9] 
Figure 16. Steel beam dimensions are also presented in Figure 16. Reference temperature determination is shown in Table 2.

Table 2. Determination of reference temperature

\begin{tabular}{|l|c|}
\hline Effect & Value \\
\hline Lowest air temperature, $T_{\min }$ & $-15^{\circ} \mathrm{C}$ \\
\hline Losses due to component radiation, $\Delta T_{r}$ & $-5 \mathrm{~K}$ \\
\hline $\begin{array}{l}\Delta T_{s} \text { (detail specified in EN 1993-1-9: transverse } \\
\text { stiffening welded onto the bottom flange) }\end{array}$ & $0 \mathrm{~K}$ \\
\hline Additional safety element, $\Delta T_{R}$ & $0 \mathrm{~K}$ \\
\hline$\dot{\varepsilon}=0,005 \mathrm{~S}^{-1}, \Delta T_{\varepsilon}$ & $-16 \mathrm{~K}^{*}$ \\
\hline No cold forming, $\Delta T_{\varepsilon c f}$ & $0 \mathrm{~K}$ \\
\hline$T_{E d}$ & $-36{ }^{\circ} \mathrm{C}$ \\
\hline$*$ calculated with $f_{y}(t)=f_{y 0}-0,25 ; t / t_{0}=355-0,25=35 / 1=346 \mathrm{~N} / \mathrm{mm}^{2}$ \\
\hline
\end{tabular}

$\Delta T_{\dot{\varepsilon}}=-\frac{1440-f_{y}(t)}{550}\left(\ln \frac{\dot{\varepsilon}}{\dot{\varepsilon}_{0}}\right)^{1,5}=$

$-\frac{1440-346}{550}\left(\ln \frac{0,005}{0,0001}\right)^{1,5}=-15,4 K \approx-16 K$

Additional information about input parameters used in expression (5) are given in [10].

Relevant stress $\sigma_{E d}$ is calculated with $\Psi_{1}=0,7$ from the exceptional load combination $(\gamma=1,0)$ and amounts to $209 \mathrm{~N} /$ $\mathrm{mm}^{2}$. This leads to stress level of $\sigma_{E d}=209 / 346 f_{y}(\mathrm{t})=0,60 f_{y}(t)$. According to table 2.1 from EN 1993-1-10 [3], the minimum toughness requirement is $T_{27}=-20{ }^{\circ} \mathrm{C}$ or $\mathrm{S} 355 \mathrm{~J} 2$, where the maximum allowable thickness (obtained by linear interpolation for $T_{E d}=-40^{\circ} \mathrm{C}$ dependant on the level of stress)

$t_{\text {permissible }}\left(0,60 f_{y}(t)\right)=47>t_{f}=35 \mathrm{~mm}$

On the other side, the steel S355 J0 $\left(T_{271}=0{ }^{\circ} \mathrm{C}\right)$ is not satisfactory as the maximum allowable thickness for such steel $t_{\text {permissible }}\left(0,60 f_{y}(t)\right)=32 \mathrm{~mm}$ is smaller than the flange thickness $t_{f}=35 \mathrm{~mm}$ that is needed based on the ultimate limit state requirement.

\subsection{Other application possibilities}

\subsubsection{Wind power plants}

Wind plant power elements are usually made of structural steel (cf. Figure 17) and so the standardized procedure described in Section 4.1 can be applied. However, it is important to take into account the deformation growth rate. According to [10], significant deformation growth rates ( $\dot{\varepsilon}=0,0001$ to $0,1 \mathrm{~s}^{-1}$ ) may be registered during wind action. Nevertheless, in most cases, a sufficiently ductile type of steel may be selected for elements that are critical from the standpoint of brittle fracture (such as connecting elements, elements installed in foundations, etc.). For that reason, fine-grained qualities of seel (e.g. S355 NL or ML) are often selected so as to ensure a sufficient resistance to brittle fracture even in situations when wind plants are built in cold weather areas. However, what are we to do with elements that are not made of usual structural steel, such as rotor centre and axle?

Axles are normally made of the improved forged steel 30CrNiMo8. In such cases, detailed analyses must be made using the basic verification format, cf. expression (1). The main problem with such analyses is collection of a sufficient quantity of data about the material, especially with regard to toughness properties and deformation rate effects. Technical delivery conditions, such as those according to EN 10083 [11], do not provide toughness requirements or, if they do, such data are not applicable for the analysis of brittle fracture as they are related to material that will subsequently be improved. Furthermore, it should be noted that the load exerted on such elements can be quite high, especially if effects of stress concentration due to change in stiffness must be taken into account (e.g. change of stiffness in the area around connection between the axle and rotor centre).

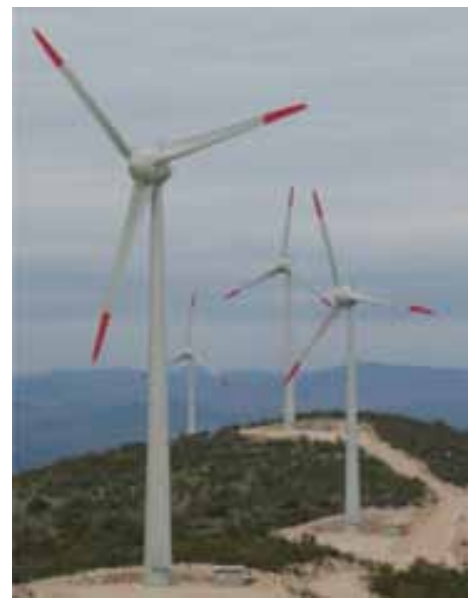

Figure 17. Trtar-Krtolin Wind Power Plant

Finally, it should also be noted that the duration of load in case of wind plants is usually different when compared to bridges. On the one side, a high number of load cycles is close to permanent strength defined during the fatigue analysis. On the other side, the number of such load cycles is much higher $(x 10$ to $\times 100)$ when compared to bridges, and the range of some of the load cycles is not much smaller than the yield limit, which is also untypical for bridges. That is why special assumptions must be adopted for the analysis, and special requirements must be set for the fabrication of such structures. This must be combined so as to ensure that assumed crack sizes are "safe" for analysis and for use in the fracture mechanics calculation. In estimation of brittle fractures, "safe" means that the initial flaw with the defined initial value can certainly be found through required quality verifications (e.g. non-destructive testing). However, in an 


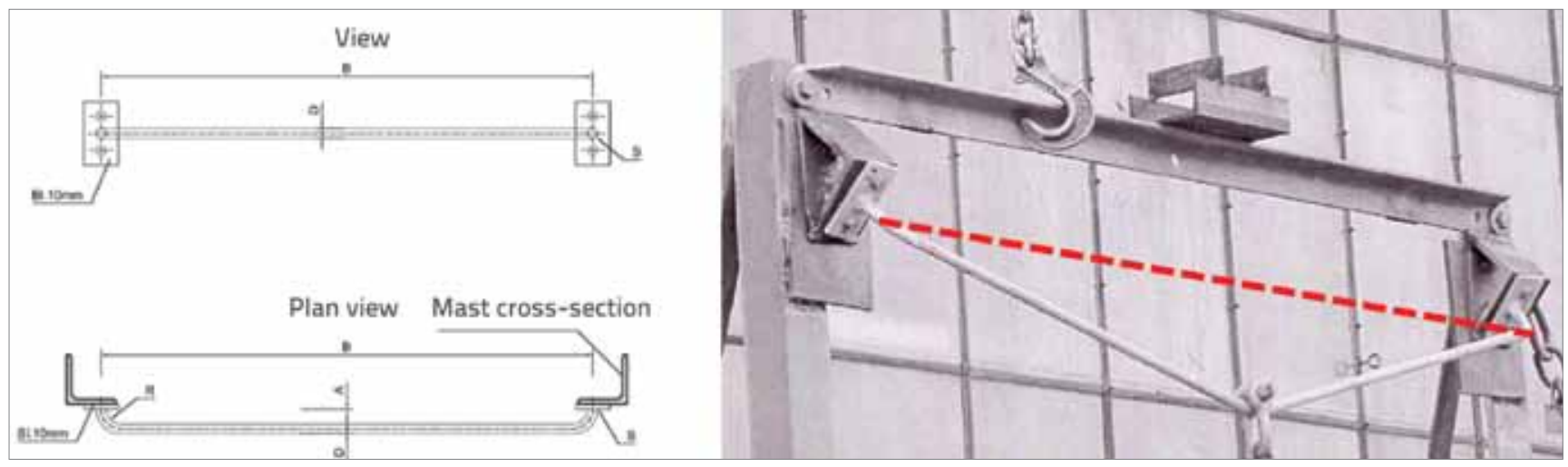

Figure 18. Example of plastic deformation of a stopping device after the fall has been stopped

"exceptional" case when such flaw is not identified, and when brittle fracture can occur under frequent loading actions, care must be taken that the time between two inspections is (optimally) shorter than the time the initial crack needs to attain the critical crack size. Correct requirements for the fabrication of axles can be:

- welding is not allowed (welding is also not allowed during repairs);

- stress concentration effects must be reduced to minimum (e.g. by smooth change in stiffness);

- there is no cold forming;

- one-hundred percent non-destructive testing (100\% NDT), with a special emphasis on the surface (cracks are not allowed, other irregularities must be situated at a sufficient distance from the surface, and surface roughness must be limited).

Based on such requirements, an "exceptional" initial size of crack must be assumed, and crack development calculations must be conducted so as to find out if sufficient time is at our disposal to identify the crack before it becomes critical. If there is enough time, the fracture mechanics calculation will show that the available toughness is greater than the toughness requirement due to crack, frequent loading and deformation rate effects.

Depending on limit condition, the analysis of brittle fracture on such elements (components) often leads to the fracture toughness requirement $K_{\text {mat }}=45-100 \mathrm{MPa} \sqrt{\mathrm{m}}$ which can be fulfilled by improved forged steel 30CrNiMo8. However, the calculated requirements must be agreed upon through contract, as such requirements are seldom included in technical requirements for delivery.

\subsubsection{Stopping devices on work platforms}

Highly reliable work platforms have to be used on some steel structures. If rails can not be installed, then stopping devices are used as a means for protecting workers from falling down. In case the worker attached to such device actually falls, the device will stop the fall. In addition, if energy dampers are used to lessen effects of the fall, then the duration of load exerted on the stopping device will often have the deformation growth rate of $\dot{\varepsilon}=0,0007 \mathrm{~s}^{-1}$. For that reason, the effects of the deformation growth rate have to be taken into account when brittle fracture is analyzed for such elements. Only several types of stopping devices have so far been studied in order to define their specific maximum deformation growth rate. However, deformation growth rates of up to $\varepsilon=10 \mathrm{~s}^{-1}$ have been obtained. It should be noted that such a small number of results can not be applied to other types of stopping devices as they are characterized by different load duration and behaviour, with respect to deformation.

In addition, some types of stopping devices exhibit great plastic deformation after the fall has been stopped, cf. Figure 18. These plastic deformations have to be taken into account even if brittle fracture calculations had been conducted for such stopping devices. According to [10], the cold forming level can be calculated by means of the following expression:

$\varepsilon_{c f}=\varepsilon_{\max }=\frac{16 f}{L(n+1)} \times \frac{h}{b} \times 100$

using symbols $f, L, h, b$ i $n$ paccording to Figure 19.

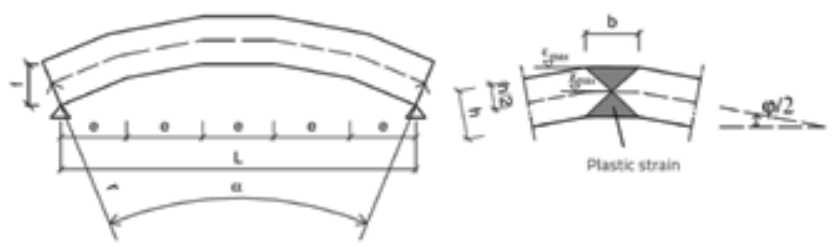

Figure 19. Symbol definitions from expression (7)

For usual dimensions of the type of stopping device that is presented in Figure 18, the expression (7) leads to the cold forming level ranging from $30 \%$ to $35 \%$. If expressions (2.3) and (2.4) from EN 1993-1-10 [3] are applied, then both effects (deformation growth rate and cold forming) lead to change of transition temperature and its movement toward the temperature of $\Delta T_{\varepsilon} \approx-75 \mathrm{~K}$ and $\Delta T_{\varepsilon \mathrm{cf}} \approx-105 \mathrm{~K}$. Considering these results, it is obvious that:

- brittle fracture analyses are recommended for all stopping devices, rather than for only those that are used in cold weather conditions, 
- if normal structural steel has to be used, additional detailed studies are recommended so that more realistic assumptions can be found for both effects arising from the earlier mentioned theoretically defined values.

The testing was conducted for the stopping device type under study, and the load-time-history during the damping of a fall, as well as the final plastic deformation, were registered. It was established that both values, strain rate $\left(\varepsilon>4 \mathrm{~S}^{-1}\right)$ and plastic deformation $\left(\varepsilon_{c f} 15 \%\right)$ are much lower than theoretically estimated. It should also be noted that both effects do not realize their maximum at the same time (maximum deformation growth rate was registered at the beginning of the fall prevention activity, while maximum level of cold forming was noted at the end), and that they usually do not occur at the same position along the element. In other words, at places where the deformation growth rate and plastic deformation have their maximum, there are no other negative effects related to brittle fracture, e.g. welds, changes in stiffness, etc. Consequently, these types of stopping devices can as a rule be made of steel S355 $\mathrm{J} 2$.

\section{Conclusion}

The European practice for proper choice of steel is based on EN 1993-1-1 which defines requirements for mechanical properties of materials - ductility, toughness, and through thickness properties. New European unified technical regulations for the design of steel structures (Eurocode 3) offer in one of its parts (EN 1993-1-10) a steel selection method avoid brittle fracture. This concept is based on the assessment of safety through fracture mechanics, and is available for different members made of structural steel. The method is usually applied for members subject to dynamic load leading to fatigue, but can also be used for members subjected to quasi-static load, [12]. As presented in this paper, the method can also be used in cases with specific toughness requirements because of high strain rate and/or considerable cold deformation effects. It can also be applied to other metalic materials.

\section{REFERENCES}

[1] European Committee for Standardization (CEN): EN 1993-1-1. Eurocode 3: Design of steel structures - Part 1-1: General rules and rules for buildings, Brussels, Belgium, 2005.

[2] European Committee for Standardization (CEN): EN 1990: Eurocode - Basis of structural design, Brussels, Belgium, 2002.

[3] Schäfer, D.; Eichler, B.; Amlung, L.; Vayas, I.; Karlos, V.; Spiliopoulos, A.; Lippe, M.; Kubon, Z.; Kander, L.: EUR 24227: Modern plastic design for steel structures, Research Fund for Coal and Steel series, Luxembourg, 2010.

[4] European Committee for Standardization (CEN): EN 1993-110. Eurocode 3: Design of steel structures - Part 1-10: Material toughness and through thickness properties, Brussels, Belgium, 2005.

[5] European Committee for Standardization (CEN): EN 10025: Hot rolled products of structural steels, Brussels, Belgium, 2004.

[6] Hechler, O.; Axmann, G.; Donnay, B.: The right choice of steel according to the Eurocode, Symposium proceedings: Use of steel materials in buildings \& construction, Hong Kong, China, 2009, pp. 01-22.
[7] Sedlacek, G.; Feldmann, M.; Kühn, B.; Tschickardt, D.; Höhler, S.; Müller, C.; Hensen, W.; Stranghöner, N.; Dahl, W.; Langenberg, P.; Münstermann, S.; Brozetti, J.; Raoul, J.; Pope, R.; Bijlaard, F.: COMMENTARY AND WORKED EXAMPLES TO EN 1993-1-10 'Material toughness and through thickness properties' and other toughness oriented rules in EN 1993. JRC Scientific and Technical Reports, Italy, 2008.

[8] European Committee for Standardization (CEN): EN 1993-19: Eurocode 3: Design of steel structures - Part 1-9: Fatigue, Brussels, Belgium, 2005.

[9] Sveučilište u Zagrebu, Gradevinski fakultet, Zavod za konstrukcije: Vijadukt Mirna - glavni projekt, knjiga 2 - dio 1: Statički proračun gornji ustroj, Zagreb, veljača 1999.

[10] Kühn, B.: Beitrag zur Vereinheitlichung der europäischen Regelungen zur Vermeidung von Sprödbruch, Dissertation am Lehrstuhl für Stahlbau, RWTH Aachen, 2005.

[11] European Committee for Standardization (CEN): EN 10083: Steels for quenching and tempering - Part 1: General technical delivery conditions, Brussels, Belgium, 2006.

[12] Höhler, S., Kühn, B., Sedlacek, G.: Brittle fracture mechanical concept for welded connections in steel structures, Proc. of the 10th Nordic Steel Conference, Copenhagen (Denmark), 7-9 June 2004, pp 65-76. 